\title{
Chekhov's Restorationist Manifesto
}

A $t$ the end of his life in the late 1850s, Henry David Thoreau composed a treatise in opposition to the creationists of his day called Faith in a Seed. However, it was published for the first time only recently (Thoreau, 1993). Its opening page includes the following passage:

We are so accustomed to see another forest spring up immediately, as a matter of course, when one is cut down (whether from the stump or from the seed), never troubling ourselves about the succession, that we hardly associate seeds with trees, and do not anticipate the time when this regular succession will cease and we shall be obliged to plant, as they do in all old countries. The planters of Europe must therefore have a different and much more correct notion of the value of seeds than we. (pp. 23-24)

Perhaps it is unfortunate for restorationists in America that these thoughts were buried for so long. A recent film reminds us that our road less travelled is full of the faded tracks of nineteenth century Europeans.

Vanya on 42nd St, Louis Malle's film version of David Mamet's translation of Anton Chekhov's play Uncle Vanya, (Mamet, 1989 ) includes one of the most spirited arguments for environmental restoration in western culture. One of the main characters, Doctor Astrov, devotes all his free time to restoring a forest, and his speeches on the subject win him the love of the female protagonists, both rich and poor. The most interesting section for restorationists is introduced when Yelena, the wealthier of his admirers, remarks about a vocation:

How interesting can that be, really, alone in the woods all the time? I should think it quite monotonous. (p. 15)

Sofya, who is poorer and much less corrupted than Yelena, says in his defense:

$\mathrm{Oh}$, not at all, no, it's quite interesting. Every year he plots new forests, or he makes a plan to conserve the old ones. He's received both a medal and a diploma for his work. (p. 15)

Yelena is doing more than flirting. She is questioning the value of a performance no one sees. Interestingly, the film itself is also a documentary of the custom that director Andre Gregory and his actors have of rehearsing Uncle Vanya in front of small groups of friends in an abandoned theater on 42nd Street in New York
City, with no intention of ever staging it for the public. In the opening sequence, Gregory is shown walking through the streets of New York thumbing a Buddhist rosary, and it is clear that the rehearsals of the play are a form of repetitive ritual, done as an act of love. The film version, then, is like the awards Astrov receives for his solitary plantings, applauding the performance of virtue even when no such recognition is solicited. Or is it solicited? How unselfconscious are Gregory and Astrov? The Buddhists say, contrary to conventional wisdom, that an act of compassion done with conscious awareness is of more lasting benefit than one done spontaneously. Is it therefore wrong for Gregory and Astrov to be aware of the kind of recognition their performances will awaken? And what do their experiences suggest about the practice of restoration as a performance?

\section{Sofya continues:}

And if you listen to him you'll see what he means. He says that forests embellish the land, that they instill in Man a love of Beauty, that they raise the mind. They moderate the climate, and, in countries with a milder climate, people struggle less with nature. $\mathrm{So}$, in those lands Man is milder, gentler. And the people in those lands are more supple and beautiful. Their speech is more refined, their movements are more graceful. (Pause.) They cultivate the Arts and Sciences ... There is joy in their philosophy ... They treat women with nobleness ... (pp. 15-16)

Is this not an early version of the idea of environmental restoration as a new sacrament? Chekhov is describing a heuristic and hermeneutic approach to nature, in which if you give something back to nature the land will give something to culture as a whole. This might be something to reflect on the next time we jog through our local arboretum.

A grumbling objection to Sofya's speech by Uncle Vanya (played in the film by none other than the redoubtable Wally Shawn) gives the doctor his cue:

Yes, sometimes we cut wood out of necessity, but why be wanton? Why? Our forests fall before the ax. Billions of trees. All perishing. The homes of birds and beasts being laid waste. The level of the rivers falls, and they dry up. And the sublime landscapes disappear ... (p. 16)

But where, as often happened to Levin, the advocate of what we now call Indigenous Knowledge Systems in Leo Tolstoy's Anna 
Karenina, and the character upon (given Tolstoy's massive influence on Chekhov) whom this aspect of the doctor's personality is probably modeled, the doctor's views are met with skepticism and mild derision, he replies:

I see. You think me amusing. These seem to you the thoughts of some poor eccentric. Perhaps, it's naive too on my part. Perhaps you think that. But I pass by the woods I've saved from the ax. I hear the forest sighing... I planted that forest. And I think: perhaps things may be in our power. You understand. Perhaps the climate itself is in our control. Why not? And if, in one thousand years, man is happy, I will have played a part in that happiness. A small part. I plant a birch tree. I watch it take root, it grows, it sways in the wind, and I feel such pride ... (pp. 16-17)

These speeches are the ethical centerpieces of the play, despite Dr. Astrov's moral failings. The doctor's merely partial success at interesting his friends in his project and the care of the land is echoed in Chekhov's last play, The Cherry Orchard, in which, as David Mamet says in his introduction to his adaptation of the play, "nobody gives a damn about the cherry orchard." Later in Uncle Vanya, the doctor fails to hold Yelena's attention at all when describing his land-use plans to her. Russian authors such as Tolstoy and Chekhov were already obsessed with the problem of how to popularize and legitimate a land ethic in the face of endemic indifference, over a hundred years ago. What can we learn from them other than a Schopenhauerian acquiescence to the inevitable evils of modernity, given the later destruction of their homeland by forces they were partly responsible for spawning? Is there not reason to hope when the otherwise idle and unhappy Yelena, later in the play, says about the doctor:
It isn't trees . . it isn't "forests" ... "medicine" ... What he has is talent ... Scope of Mind. He plants a tree, and when he plants it he sees, he is trying to see what comes of his action in a thousand years. A thousand years. D'you know? He's thinking of the Happiness of Man. When you find such beautiful people ... they must be loved. (p. 40)

The doctor's lonely performance does not pass unnoticed after all, unlike Levin's religious awakening at the end of Anna Karenina. There is a qualitative difference between the simplicity of Levin's identification with the peasants' old time, creationist religion and Astrov's active, scientific vison of the future. If, as the American post-modernist poet Charles Olson said, "art is the knowledge of consequences," then ecological restoration falls solidly on the side of art. So does Vanya on 42nd Street. Restorationists should not miss this edifying and excellent film.

\section{BIBLIOGRAPHY}

Clyman, Toby W., editor. 1985. A Chekhov companion. Westport, CT: Greenwood Press.

Mamet, David. 1987. The cherry orchard by Anton Chekhov. Adapted by David Mamet from a literal translation by Peter Nelles. 1st Grove Press edition. New York: Grove Press.

Mamet, David. 1989. Uncle Vanya by Anton Chekhov. Adapted by David Mamet from a literal translation by Vlada Chernomirdik. New York: Grove Press.

Thoreau, Henry David. 1993. Faith in a seed: The dispersion of seeds and other late natural history writings. Edited by Bradley P. Dean. Washington, D.C.: Island Press/Shearwater Books.
Alex Turner
Madison, Wisconsin
alturner@students.wisc.edu 